\title{
PENGELOLAAN EKOWISATA MANGROVE BERDASARKAN DAYA DUKUNG EKOSISTEM DAN PERSEPSI MASYARAKAT
}

\author{
Wiharso $0^{1,2}$ \\ Ernik Yuliana1 \\ Eddy Supriono ${ }^{3}$ \\ 1) Program Pascasarjana Universitas Terbuka \\ 2) Balai Pemantapan Kawasan Hutan Wilayah XII Tanjungpinang \\ 3) Institut Pertanian Bogor \\ e-mail: champion1areso@gmail.com
}

\begin{abstract}
Currently, mangrove ecotourism is interesting by the community. Berakit Village, Teluk Sebong Subdistrict, Bintan Regency, Riau Islands Province has a mangrove ecosystem that is used as an ecotourism area and is starting to be visited by many visitors. The aim of the study was to analyze the management of mangrove ecotourism based on the carrying capacity of the ecosystem and community perceptions. Data collection on mangrove potential was carried out through a mangrove inventory on 10 transect lines, perception and socio-economic data collection was carried out through interviews by giving questionnaires to respondents, as many as 60 surrounding communities and 30 visitors, with a simple random sampling technique. Data analysis using the Tourism Conformity Index (IKW), Carrying Capacity Area (DDK) ecotourism for roaming tours of mangrove tracks. The results showed that IKW reached $87.50 \%$ (very suitable), and DDK ecotourism mangrove tracks with wooden bridges were 214 people per day, while for mangrove cruising tours boating was 231 people per day. Respondents' perceptions of mangrove ecotourism and their management are good, and have the potential to be developed for ecotourism activities. The ecotourism management strategy that can be chosen is to promote and publicize mangrove tourism in Berakit Village, develop attractive ecotourism packages, provide garbage dumps at the crowds and do beach cleaning which is affected by pollution from oil spills.
\end{abstract}

Keywords: Berakit Village, mangrove, ecotourism

\begin{abstract}
ABSTRAK
Ekowisata mangrove saat ini banyak diminati oleh masyarakat. Desa Berakit, Kecamatan Teluk Sebong, Kabupaten Bintan, Provinsi Kepulauan Riau mempunyai ekosistem mangrove yang dijadikan sebagai kawasan ekowisata dan mulai banyak dikunjungi oleh masyarakat. Tujuan penelitian adalah menganalisis pengelolaan ekowisata mangrove berdasarkan daya dukung ekosistem dan persepsi masyarakat. Pengambilan data potensi mangrove dilakukan melalui inventarisasi mangrove pada 10 jalur transek, pengambilan data persepsi dan sosial ekonomi dilakukan melalui wawancara dengan memberi kuesioner kepada 90 responden, 60 masyarakat sekitar dan 30 pengunjung, dengan teknik simple random sampling. Analisis data menggunakan Indeks Kesesuaian Wisata (IKW), Daya Dukung Kawasan (DDK) ekowisata untuk wisata jelajah mangrove track. Hasil penelitian menunjukkan bahwa IKW mencapai 87,50\% (sangat sesuai), dan DDK ekowisata mangrove
\end{abstract}


track dengan jembatan kayu adalah 214 orang/hari, sedangkan untuk wisata jelajah mangrove dengan berperahu adalah 231 orang/hari. Persepsi responden tentang ekowisata mangrove dan pengelolaannya adalah baik, serta berpotensi untuk dikembangkan untuk kegiatan ekowisata. Strategi pengelolaan ekowisata yang dapat dipilih adalah melakukan promosi dan publikasi mengenai ekoswisata mangrove di Desa Berakit, mengembangkan paket ekowisata yang menarik, menyediakan tempat pembuangan sampah pada titik keramaian dan melakukan pembersihan pantai yang terdampak pencemaran akibat tumpahan minyak.

Kata kunci: Desa Berakit, mangrove, ekowisata

Ekosistem mangrove merupakan ekosistem yang khas daerah tropis. Tanaman penyusun komunitas mangrove adalah tanaman asli terestrial, namun mereka sudah mampu beradaptasi dengan tingginya tingkat garam lingkungannya. Ekosistem mangrove didominasi oleh tumbuhan yang khas di sepanjang pesisir pantai dan sepanjang sungai yang mendapat pengaruh pasang surut dari air laut, misalnya jenis bakau (Rhizopora spp), nyirih (Xylocarpus spp), tanjang (Bruguiera spp) dan api-api (Avicennia spp) (Kusumastanto, Damar, \& Adrianto, 2012).

Desa Berakit, Kecamatan Teluk Sebong, Kabupaten Bintan, Provinsi Kepulauan Riau mempunyai ekosistem mangrove yang dijadikan sebagai kawasan ekowisata. Ekowisata merupakan wisata yang dikelola dengan pendekatan konservasi guna menjaga kelestarian sumber daya alam dengan tetap mempertahankan keutuhan dan keaslian ekosistem di areal yang masih alami sebagai tujuan wisata. Dalam pengembangannya ekowisata memberikan perhatian besar terhadap kelestarian sumberdaya alam (termasuk mangrove), sebagai suatu bentuk perjalanan wisata alam yang bertanggung jawab dengan tetap mengkonservasi lingkungan (Triastuti, 2015). Perbedaan ekowisata dengan wisata pada umumnya adalah ekowisata merupakan kegiatan wisata untuk melestarikan sumber daya alam dan lingkungan sebagai tujuan utama, sedangkan wisata biasa kurang menekankan pada konservasi sumber daya alam dan lingkungan.

Ekowisata mangrove di Kabupaten Bintan cukup menjanjikan jika dikelola dengan baik. Jumlah kunjungan wisatawan di Kabupaten Bintan pada tahun 2016 sebanyak 305.404 orang (Badan Pusat Statistik, 2017). Peran masyarakat terhadap keberhasilan pelestarian ekosistem mangrove sangat penting. Kegiatan pelestarian ekosistem mangrove akan berjalan dengan sukses jika ada keterlibatan dan motivasi yang tinggi dari masyarakat sekitar dalam pengelolaan ekosistem mangrove. Pengembangan ekowisata mangrove juga dapat menjadi alternatif dalam membangun dan mendukung pelestarian ekosistem mangrove sehingga dapat menekan laju degradasi ekosistem mangrove.

Pengelolaan ekowisata mangrove di Desa Berakit belum maksimum sehingga perlu masukan dari beberapa pihak agar pengelolaannya menjadi lebih biak. Penelitian ini berusaha untuk memberikan masukan terhadap pengelolaan ekowisata mangrove di Desa Berakit, dari aspek daya dukung ekosistem mangrove sebagai kawasan ekowisata dan persepsi masyarakat terhadap jasa ekosistem dan pengelolaan ekowisata mangorve. Keberhasilan wisata mangrove dapat disebabkan oleh kombinasi beberapa faktor yaitu aksesibilitas lokasi mangrove, keterlibatan masyarakat setempat, kualitas ekosistem mangrove, dan ketersediaan program wisata mangrove (Hakim, Siswanto, \& Nakagoshi, 2017). Pengembangan ekowisata mangrove juga dapat menjadi alternatif 
dalam membangun dan mendukung pelestarian ekosistem mangrove sehingga dapat menekan laju degradasi ekosistem mangrove.

Pengelolaan ekowisata mangrove di Desa Berakit belum maksimum sehingga perlu masukan dari beberapa pihak agar pengelolaannya menjadi lebih biak. Penelitian ini berusaha untuk memberikan masukan terhadap pengelolaan ekowisata mangrove di Desa Berakit, dari aspek daya dukung ekosistem mangrove sebagai kawasan ekowisata dan persepsi masyarakat terhadap jasa ekosistem dan pengelolaan ekowisata mangrove. Sebagaimana penelitian Rahmila \& Halim (2018), yang menyimpulkan bahwa untuk pengembangan ekowisata mangrove di Mangunharjo, perlu menghitung daya dukung ekosistemmya.

Tujuan penelitian secara lebih lengkap adalah menganalisis: 1) Daya dukung ekosistem mangrove untuk dikembangkan sebagai ekowisata; 2) Kesesuaian ekosistem mangrove di Desa Berakit dengan indikator ekowisata mangrove; 3) Persepsi masyarakat dan pengunjung tentang kondisi mangrove dan jasa ekosistem mangrove; 4) Strategi pengelolaan ekowisata mangrove menuju pengelolaan yang lebih baik.

\section{METODE}

Lokasi penelitian Desa Berakit, Kecamatan Teluk Sebong, Kabupaten Bintan, Provinsi Kepulauan Riau. Pengambilan data potensi mangrove dilakukan melalui inventarisasi mangrove pada 10 jalur transek. Pengambilan data mengenai persepsi dan sosial ekonomi dilakukan melalui survei dengan memberi kuesioner kepada responden dengan teknik simple random sampling. Jumlah sampel sebanyak 90 terdiri dari 60 responden masyarakat sekitar mangrove dan 30 responden pengunjung. Analisis data dilakukan sebagai berikut.

1. Potensi ekosistem, kesesuaian wisata, daya dukung kawasan menggunakan analisis kesesuaian wisata dan daya dukung kawasan (Yulianda, 2007):

$$
\mathrm{KW}=\sum\left(\frac{N i}{N \max }\right) \times 100 \%
$$

Keterangan:

$\mathrm{IKW}=$ Indeks Kesesuaian Wisata Sangat sesuai $(\mathrm{S} 1)=80 \%-100 \%$, sesuai (S2) $60 \%-80 \%$, sesuai bersyarat $(S 3)=35 \%-60 \%$, tidak sesuai $(\mathrm{N})<35 \%)$.

$\mathrm{Ni}=$ Nilai parameter ke-I (Bobot $x$ Skor $)$

Nmax = Penjumlahan hasil pengalian nilai bobot dengan nilai skor.

$\mathrm{DDK}=\mathrm{K} \times \frac{\mathrm{Lp}}{\mathrm{Lt}} \times \frac{\mathrm{Wt}}{\mathrm{Wp}}$
Keterangan:
DDK = Daya Dukung Kawasan
$\mathrm{K}=$ = Potensi ekologis pengunjung per unit area (orang per $\mathrm{m}^{2}$ )
$\mathrm{Lp} \quad=$ Luas atau Panjang area yang dapat digunakan $\left(\mathrm{m}^{2}\right)$
$\mathrm{Lt} \quad=$ Unit area $\left(\mathrm{m}^{2}\right)$
Wt = Waktu yang disediakan kawasan (jam/hari)
$\mathrm{Wp} \quad=$ Waktu yang dihabiskan pengunjung (jam/hari) 
Analisis kesesuaian dan daya dukung ekowisata mangrove menggunakan matriks seperti yang disajikan pada Tabel 1.

Tabel 1. Matriks Kesesuaian Kawasan Wisata

\begin{tabular}{|c|c|c|c|c|c|c|c|c|c|}
\hline Parameter & $B$ & $\begin{array}{l}\text { Kategori } \\
\text { S1 }\end{array}$ & $S$ & $\begin{array}{l}\text { Kategori } \\
\text { S2 }\end{array}$ & $S$ & $\begin{array}{l}\text { Kategori } \\
\text { S3 }\end{array}$ & $S$ & Katgori & $S$ \\
\hline $\begin{array}{l}\text { Ketebalan } \\
\text { mangrove (m) }\end{array}$ & 5 & $>500$ & 4 & $>200-500$ & 3 & $50-200$ & 2 & $<50$ & 1 \\
\hline $\begin{array}{l}\text { Kerapatan }(1 \mathrm{nd} / 100 \\
\left.\mathrm{m}^{2}\right)\end{array}$ & 4 & $>15-25$ & 4 & $>10-15$ & 3 & $5-10$ & 2 & $<5$ & 1 \\
\hline Jenis Mangrove & 4 & $>5$ & 4 & $3-5$ & 3 & $1-2$ & 2 & 0 & 1 \\
\hline Pasang Surut (m) & 3 & $0-1$ & 4 & $>1-2$ & 3 & $>2-5$ & 2 & $>5$ & 1 \\
\hline \multirow[t]{2}{*}{ Objek Biota } & 3 & $(>5)$ & 4 & $(3-5)$ & 3 & (2) & 2 & $(0-1)$ & 1 \\
\hline & & $\begin{array}{l}\text { Ikan, Udang, } \\
\text { Kepiting, } \\
\text { Moluska, Reptil, } \\
\text { Burung }\end{array}$ & & $\begin{array}{l}\text { Ikan, Udang, } \\
\text { Kepiting, } \\
\text { Moluska }\end{array}$ & & $\begin{array}{l}\text { Ikan, } \\
\text { Moluska }\end{array}$ & & $\begin{array}{l}\text { Salah Satu } \\
\text { biota }\end{array}$ & \\
\hline $\begin{array}{l}\text { Karakteristik } \\
\text { Kawasan }\end{array}$ & 2 & 4 ketentuan & 4 & 3 ketentuan & 3 & 2 ketentuan & 2 & 1 ketentuan & 1 \\
\hline Aksesibilitas & 1 & 4 ketentuan & 4 & 3 ketentuan & 3 & 2 ketentuan & 2 & 1 ketentuan & 1 \\
\hline
\end{tabular}

Sumber: Yulianda (2007)

(Keterangan: a) $\mathrm{B}=$ bobot; $\mathrm{S}=$ skor; $\mathrm{S} 1$ = sangat sesuai; $\mathrm{S} 2$ = sesuai; $\mathrm{S} 3$ = sesuai bersyarat; $\mathrm{N}$ = tidak sesuai)

b) Ketentuan indikator karakteristik kawasan: 1) adanya objek yang menarik berupa flora, fauna, atau fisik; 2) terdapat panorama atau keindahan yang memiliki daya tarik tertentu; 3) bentang alam yang indah seperti gunung, bukit, dan sungai; 4) satwa dan tumbuhan langka yang dilindungi

c) Ketentuan indikator aksesibilitas: 1) jalan yang bagus dan beraspal menuju lokasi; 2) banyak jalan alternatif menuju lokasi; 3) banyak alat angkut menuju lokasi; 4) terdapat sarana pendukung berupa terminal dan pelabuhan.

2. Hasil pengisian kuesioner untuk persepsi masyarakat dianalisis secara deskriptif.

3. Penentuan strategi pengelolaan dilakukan dengan analisis SWOT.

\section{HASIL DAN PEMBAHASAN \\ Kesesuaian Kawasan Wisata}

Analisis kesesuaian kawasan ekowisata mangrove dilakukan dengan menggunakan matriks kesesuain Kawasan wisata (Tabel 1).

\section{Ketebalan Mangrove}

Hasil pengukuran ketebalan mangrove pada 10 jalur transek disajikan pada Tabel 2. Hasil pengukuran ketebalan mangrove jika diplotkan ke dalam peta, terlihat seperti disajikan pada Gambar 1. Berdasarkan hasil pengukuran ketebalan mangrove diketahui bahwa ekosistem mangrove memiliki ketebalan rata-rata 463,91 m yang termasuk pada kategori sesuai (S2) dengan skor 3 (tiga). Jalur transek yang mempunyai ketebalan paling tinggi adalah jalur 2 yaitu 830,28 $\mathrm{m}$ dan yang ketebalan paling rendah adalah jalur 5 dengan ketebalan $254,75 \mathrm{~m}$. 
Tabel 2. Hasil Pengukuran Ketebalan Mangrove

\begin{tabular}{cc}
\hline Jalur Transek & Ketebalan mangrove $(\mathrm{m})$ \\
\hline 1 & 320,88 \\
2 & 830,28 \\
3 & 397,43 \\
4 & 507,46 \\
5 & 254,75 \\
6 & 552,05 \\
7 & 288,95 \\
8 & 479,54 \\
9 & 350,48 \\
10 & 657,30 \\
\hline Rata-rata & 436,91 \\
\hline
\end{tabular}

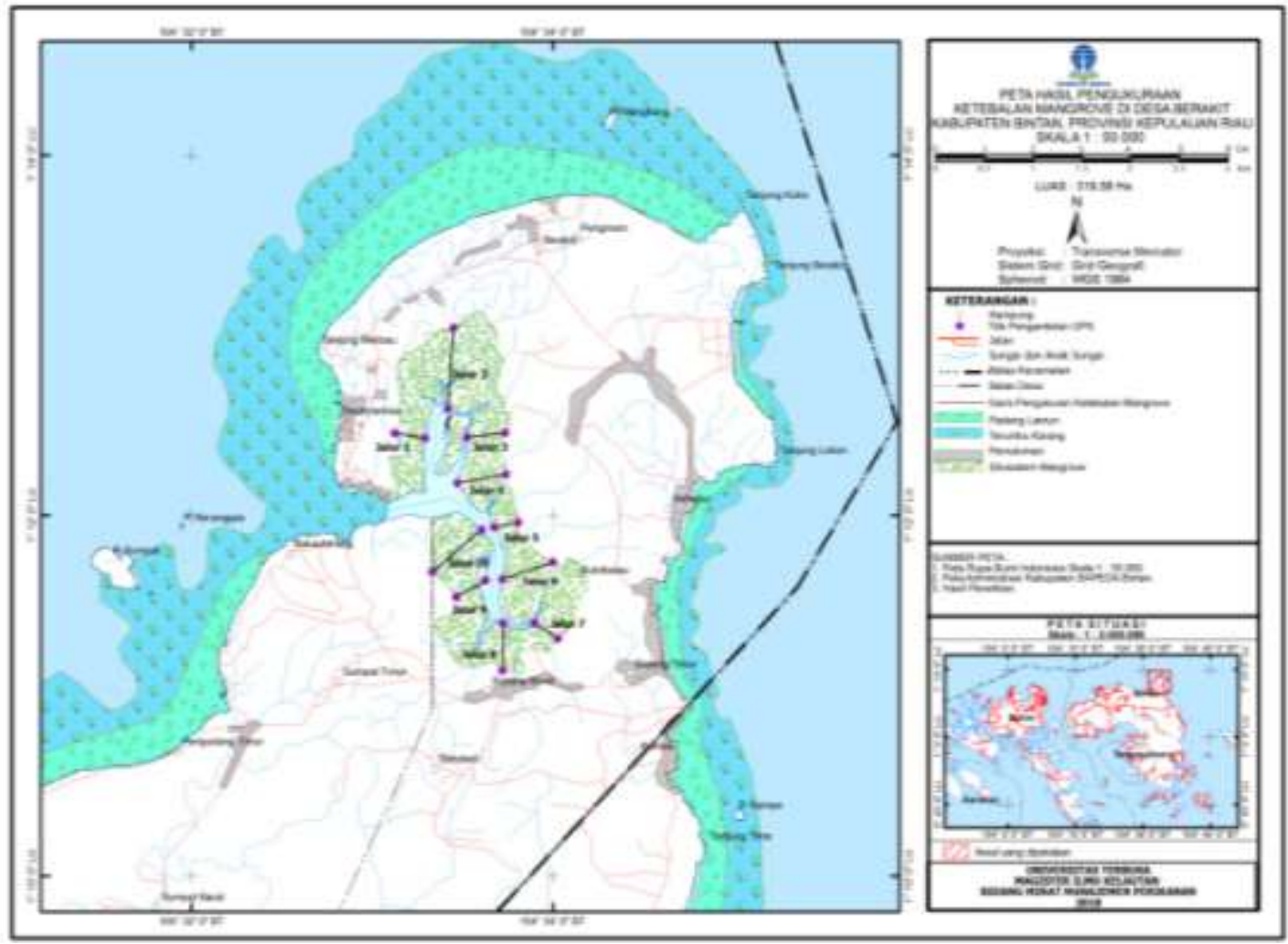

Gambar 1. Peta hasil pengukuran ketebalan mangrove

\section{Kerapatan Mangrove}

Hasil pengukuran kerapatan pada tingkat pohon adalah 15,96 ind/100 m². termasuk pada kriteria baik/sangat padat, termasuk kategori sangat sesuai (S1) dengan skor 4 (empat). Indeks nilai penting (INP) tingkat pohon untuk semua jenis mangrove disajikan pada Tabel 3. Indeks nilai penting 
(INP) tertinggi ditemukan pada pohon jenis Xylocarpus garantum sebesar $83,19 \%$, sedangkan INP terendah ditemukan pada pohon jenis Lumnitzera littorea 1,45\%.

\section{Jenis Mangrove}

Hasil inventarisasi menunjukkan bahwa terdapat 10 jenis vegetasi mangrove tingkat pohon yang ditemukan pada 10 jalur transek. Jenis vegetasi mangrove tersebut adalah api-api (Avicennia marina), tumu (Bruguera gymnorhiza), bakau hitam (Rizhopora mucronata), bakau minyak (Rizhopora apiculata), nyirih (Xylocarpus granatum), cingam (Scyphipora hydrophyllaceae), teruntum (Lumnitzera racemosa), sesup (Lumnitzera littorea), tengar (Ceriops sp), perepat (Sonneratia alba). Berdasarkan jumlah jenis yang ditemukan maka disimpulkan termasuk kategori sangat sesuai (S1) dengan skor 4 (empat).

Tabel 3. Hasil Analisis Vegetasi Pada Tingkat Pohon

\begin{tabular}{|c|c|c|c|c|c|c|c|c|c|c|}
\hline Nama Species & V & LBDS & $\begin{array}{l}\text { Jumlah } \\
\text { Individu }\end{array}$ & $\begin{array}{c}\mathrm{K} \\
\text { (ind/ha) }\end{array}$ & $\mathrm{KR}$ & $\mathrm{F}$ & FR & $\begin{array}{c}D \\
\mathrm{~m}^{2} / \mathrm{ha}\end{array}$ & DR & $\begin{array}{c}\text { INP } \\
\text { (KR+FR } \\
+\mathrm{DR})\end{array}$ \\
\hline $\begin{array}{l}\text { Avicennia } \\
\text { marina }\end{array}$ & 2,70 & 0,87 & 30 & 60 & $3,76 \%$ & 0,26 & $7,14 \%$ & 1,74 & $2,96 \%$ & $13,86 \%$ \\
\hline $\begin{array}{l}\text { Bruguera } \\
\text { hainesii }\end{array}$ & 11,30 & 2,90 & 53 & 106 & $6,64 \%$ & 0,34 & $9,34 \%$ & 5,81 & $9,88 \%$ & $25,86 \%$ \\
\hline Ceriops sp & 0,45 & 0,16 & 4 & 8 & $0,50 \%$ & 0,04 & $1,10 \%$ & 0,32 & $0,54 \%$ & $2,14 \%$ \\
\hline $\begin{array}{l}\text { Lumnitzera } \\
\text { littorea }\end{array}$ & 0,09 & 0,03 & 2 & 4 & $0,25 \%$ & 0,04 & $1,10 \%$ & 0,06 & $0,10 \%$ & $1,45 \%$ \\
\hline $\begin{array}{l}\text { Lumnitzera } \\
\text { racemosa }\end{array}$ & 1,60 & 0,46 & 13 & 26 & $1,63 \%$ & 0,16 & $4,40 \%$ & 0,93 & $1,58 \%$ & $7,60 \%$ \\
\hline $\begin{array}{l}\text { Rizhopora } \\
\text { apiculata }\end{array}$ & 9,06 & 3,85 & 206 & 412 & $25,81 \%$ & 0,76 & $20,88 \%$ & 7,70 & $13,10 \%$ & $59,79 \%$ \\
\hline $\begin{array}{l}\text { Rizhopora } \\
\text { mucronata }\end{array}$ & 12,35 & 5,00 & 290 & 580 & $36,34 \%$ & 0,68 & $18,68 \%$ & 10,01 & $17,03 \%$ & $72,05 \%$ \\
\hline $\begin{array}{l}\text { Scyphiphora } \\
\text { hydrophylacea }\end{array}$ & 4,39 & 1,52 & 55 & 110 & $6,89 \%$ & 0,52 & $14,29 \%$ & 3,03 & $5,16 \%$ & $26,34 \%$ \\
\hline $\begin{array}{l}\text { Sonneratia } \\
\text { alba }\end{array}$ & 1,42 & 0,42 & 15 & 30 & $1,88 \%$ & 0,16 & $4,40 \%$ & 0,85 & $1,45 \%$ & $7,72 \%$ \\
\hline $\begin{array}{l}\text { Xylocarpus } \\
\text { garantum }\end{array}$ & 48,06 & 14,17 & 130 & 260 & $16,29 \%$ & 0,68 & $18,68 \%$ & 28,34 & $48,22 \%$ & $83,19 \%$ \\
\hline Jumlah & 91,42 & 29,386 & 798 & 1,596 & $100,00 \%$ & 3,64 & $100,00 \%$ & 58,77 & $100,00 \%$ & $300,00 \%$ \\
\hline
\end{tabular}

Keterangan: V = volume; LBDS = luas bidang dasar; $\mathrm{K}=$ kerapatan; KR = kerapatan reltaif;

$F=$ frekuensi; $F R=$ frekuensi relatif; $D=$ dominansi; $D R=$ dominansi relatif; INP = indeks nilai penting.

\section{Pasang Surut}

Tipe pasang surut di kawasan ekosistem mangrove di Desa Berakit adalah tipe campuran condong ke harian ganda. Pola pasang surut di perairan Kabupaten Bintan pada bulan Januari disajikan pada Gambar 2. Kisaran pasang surut pada ekosistem mangrove adalah 2,6 m sehingga termasuk kategori sesuai bersyarat (S3) dengan skor 2 (dua). 


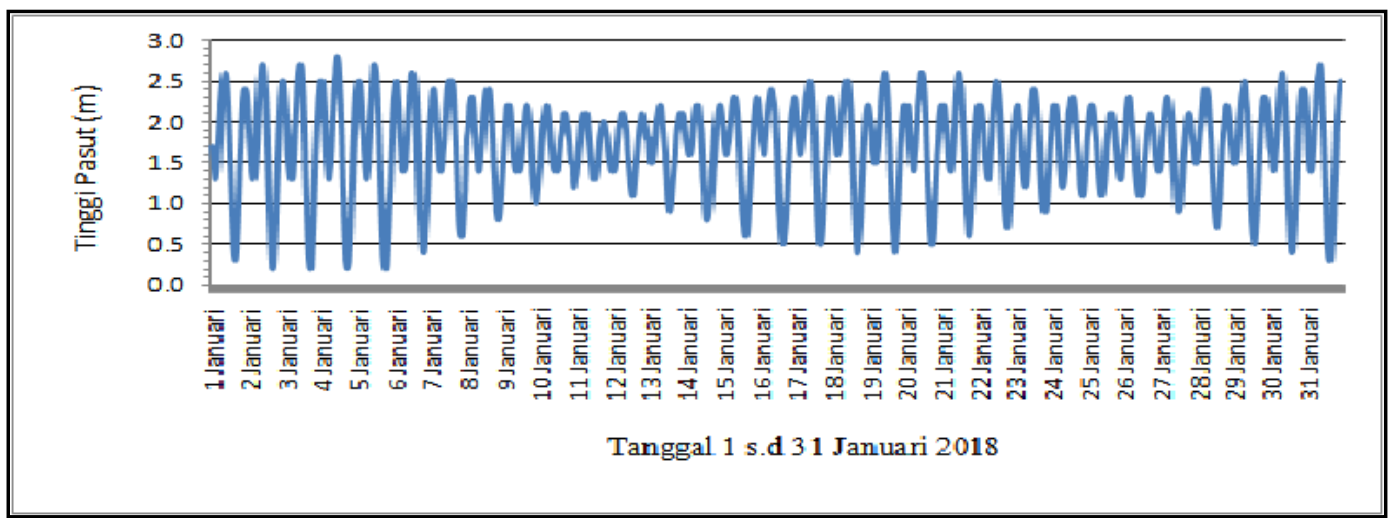

Gambar 2. Pola Pasang Surut di Perairan Pesisir Kabupaten Bintan (Sumber: Pusat
Hidrografi dan Oceanografi TNI AL, 2018)

\section{Objek Biota}

Berdasarkan hasil pengamatan di lapangan, objek biota mangrove yang ditemukan disajikan pada Tabel 4.

Tabel 4. Objek Biota pada Ekosistem Mangrove

\begin{tabular}{|c|c|c|c|c|}
\hline \multirow{2}{*}{\multicolumn{3}{|c|}{ Objek Biota }} & \multicolumn{2}{|c|}{ Status Konservasi } \\
\hline & & & IUCN Red List & CITIES \\
\hline \multirow[t]{4}{*}{ Ikan } & Unggar & Lutjanus sp & Least Concern & \\
\hline & Lebam & Siganus javus & Least Concern & \\
\hline & Buntal & Arothron meleagris & Least Concern & \\
\hline & Kuda laut & Hippocampus kuda & Vulnerable & Appendiks II \\
\hline Udang & Udang muara & Macrobrachium equidens & Least Concern & \\
\hline \multirow[t]{2}{*}{ Kepiting } & Kepiting bangkang & Scylla serrata & Not evaluated & \\
\hline & Kepiting biola & Uca rosea & Not evaluated & \\
\hline \multirow{5}{*}{$\begin{array}{l}\text { Molusca dan } \\
\text { invertebrata }\end{array}$} & Siput ranga & Lambis lambis & Not evaluated & \\
\hline & Siput anjing/ gonggong & Canarium laevistrombus & Not evaluated & \\
\hline & Blencong & Telescopium telescopium & Least Concern & \\
\hline & Kerang & Anadara granosa & Not evaluated & \\
\hline & Umang-umang & Clibanarius sp & Not evaluated & \\
\hline Reptil & Biawak & Varanus sp & Not evaluated & \\
\hline \multirow[t]{8}{*}{ Burung } & Jalak kerbau & Acridotheres javanicus & Vulnerable & \\
\hline & Punai pengantin & Treron vermans & Not evaluated & \\
\hline & Tiong lampu & Eurystomus orientalls & Not evaluated & \\
\hline & Camar & Larus sp & Not evaluated & \\
\hline & Angsa batu coklat & Sula leucogaster & Least Concern & \\
\hline & Elang bondol & Haliastur indus & Least Concern & Appendiks II \\
\hline & Pleci / Kaca mata laut & Zosterops chloris & Least Concern & \\
\hline & Gagak & Corvus sp & Not evaluated & \\
\hline
\end{tabular}




\begin{tabular}{|c|c|c|c|c|}
\hline & \multirow{2}{*}{\multicolumn{2}{|c|}{ Objek Biota }} & \multicolumn{2}{|c|}{ Status Konservasi } \\
\hline & & & \multirow{2}{*}{$\begin{array}{c}\text { IUCN Red List } \\
\text { Not evaluated }\end{array}$} & \multirow[t]{2}{*}{ CITIES } \\
\hline & Bangau putih & Egreetta $s p$ & & \\
\hline & Cinenen & Orthotomus sp & Least Concern & \\
\hline & Kacer & Copsychus saularis & Least Concern & \\
\hline Mamalia & Monyet kra & Macaca fascicularis & Least Concern & \\
\hline
\end{tabular}

Objek biota pada ekosistem mangrove yang ditemukan ada sebanyak 7 biota. Berdasarkan matriks kesesuaian, kategori untuk indikator tersebut adalah sangat sesuai (S1) dengan skor 4. Dilihat dari 4 ketentuan pada parameter karakteristik kawasan, ekosistem mangrove di Desa Berakit memiliki 4 ketentuan tersebut sehingga termasuk pada kategori sangat sesuai (S1) dengan skor 4 (empat).

\section{Aksesibilitas}

Pada indikator aksesibilitas, ekosistem mangrove di Desa Berakit memiliki 4 ketentuan sehingga termasuk pada kategori sangat sesuai (S1) dengan skor 4 (empat). Peta aksesibilitas untuk menuju Desa Berakit disajikan pada Gambar 3.

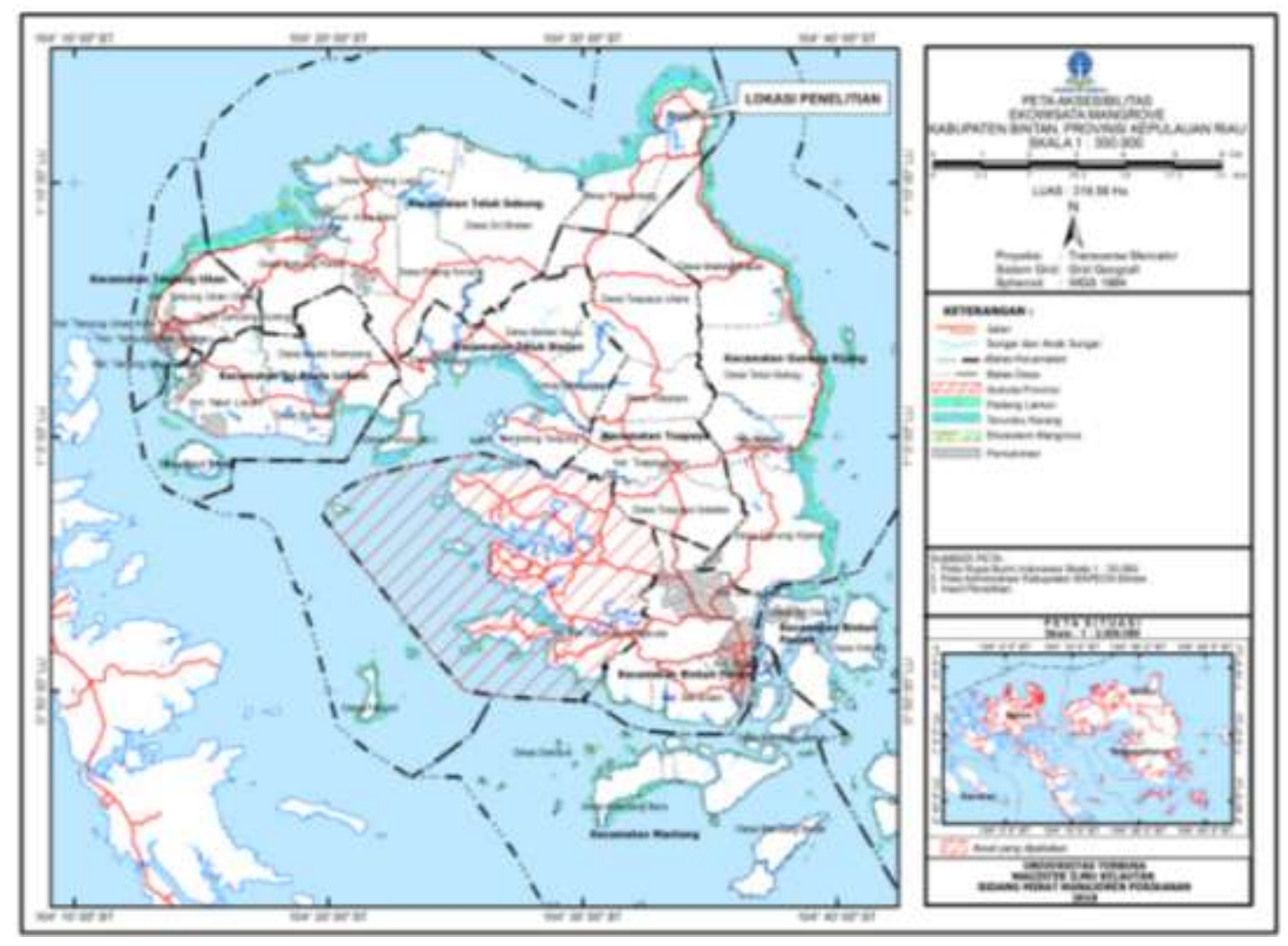

Gambar 3. Peta aksesibilitas ekowisata mangrove desa berakit 
Berdasarkan tujuh indikator kesesuaian ekosistem mangrove sebagai kawasan ekowisata, maka hasil pengamatan yang sudah dijelaskan, dituangkan ke dalam matriks, disajikan pada Tabel 5.

Tabel 5. Indeks Kesesuaian Wisata Ekosistem Mangrove Desa Berakit

\begin{tabular}{|c|c|c|c|c|c|}
\hline Parameter & Bobot & Hasil Penelitian & Kategori & Skor & $\begin{array}{l}\text { Total } \\
\text { Skor }\end{array}$ \\
\hline $\begin{array}{l}\text { Ketebalan } \\
\text { mangrove }\end{array}$ & 5 & $463,75 \mathrm{~m}$ & S2 (>200-500 meter) & 3 & 15 \\
\hline Kerapatan & 4 & $15,95 \mathrm{ind} / 100 \mathrm{~m}^{2}$ & $\mathrm{~S} 1(>15-25)$ & 4 & 16 \\
\hline Jenis Mangrove & 4 & 10 jenis & S1 (>5 jenis) & 4 & 16 \\
\hline Pasang Surut & 3 & $2,6 \mathrm{~m}$ & $S 3(>2-5)$ & 2 & 6 \\
\hline Obyek Biota & 3 & 7 kelompok jenis & S1 (>5 kelompok jenis) & 4 & 12 \\
\hline $\begin{array}{l}\text { Karakteristik } \\
\text { Kawasan }\end{array}$ & 2 & 4 ketentuan & S 1 (4 ketentuan) & 4 & 8 \\
\hline Aksesibilitas & 1 & 4 ketentuan & S 1 (4 ketentuan) & 4 & 4 \\
\hline Total Skor & & & & & 77 \\
\hline \multicolumn{3}{|c|}{ Indeks Kesesuaian wisata } & & & $87,50 \%$ \\
\hline
\end{tabular}

Berdasarkan matriks Indeks Kesesuaian Wisata (Tabel 3) pada ekosistem mangrove di Desa Berakit adalah $87,50 \%$ sehingga termasuk pada kategori sangat sesuai (S1).

\section{Daya Dukung Kawasan}

Selaian analisis kesesuaian ekosistem mangrove sebagai ekowisata, dilakukan juga penghitungan daya dukung kawasan (DDK) ekowisata disajikan pada Tabel 6.

Tabel 6. Daya Dukung Kawasan Ekosistem Mangrove

\begin{tabular}{lcccccc}
\hline $\begin{array}{l}\text { Kegiatan } \\
\text { Wisata }\end{array}$ & $\begin{array}{c}\text { Potensi } \\
\text { Ekologis } \\
(\mathrm{K})\end{array}$ & $\begin{array}{c}\text { Unit area } \\
(\mathrm{Lt})\end{array}$ & $\begin{array}{c}\text { Luas Tracking } \\
(\mathrm{Lp})\end{array}$ & $\begin{array}{c}\text { Waktu untuk } \\
\text { berwisata } \\
(\mathrm{Wt})\end{array}$ & $\begin{array}{c}\text { Waktu } \\
1 \text { hari } \\
(\mathrm{Wp})\end{array}$ & $\begin{array}{c}\text { Daya Dukung } \\
\text { Kawasan } \\
(\mathrm{DDK})\end{array}$ \\
\hline $\begin{array}{l}\text { Jelajah Track } \\
\text { Mangrove }\end{array}$ & 1 orang & $50 \mathrm{~m}^{2}$ & $\begin{array}{l}3 \mathrm{~m} \times 892,62 \mathrm{~m} \\
=2.678,06 \mathrm{~m}^{2}\end{array}$ & 2 jam & 8 jam & 214 orang/hari \\
$\begin{array}{l}\text { Jelajah } \\
\begin{array}{l}\text { Mangrove } \\
\text { berperahu }\end{array}\end{array}$ & 1 orang & $500 \mathrm{~m}^{2}$ & $\begin{array}{l}3 \mathrm{~m} \times 4.830,12 \mathrm{~m} \\
=14.490,37 \mathrm{~m}^{2}\end{array}$ & 1 jam & 8 jam & 231 orang/hari \\
\hline
\end{tabular}

Hasil penghitungan daya dukung kawasan ekosistem mangrove untuk wisata jelajah mangrove track dengan jembatan kayu adalah 214 orang/hari, sedangkan untuk wisata jelajah mangrove dengan berperahu adalah 231 orang/hari.

\section{Persepsi Masyarakat tentang Ekowisata Mangrove dan Pengelolaannya}

Berdasarkan analisis persepsi masyarakat (Tabel 7), didapatkan persepsi masyarakat dan pengunjung tentang ekowisata dan kondisi ekosistem mangrove rata-rata adalah baik. Persepsi adalah proses penerimaan informasi dari serangkaian aktivitas stimulasi yang diterima, diubah dan disebarkan (Chanafi, Fauzi, \& Sunarti, 2015). Hasil survei Masyarkat setuju jika pengelolaan 
mangrove secara lestari dengan melibatkan investor dan masyarakat sesuai dengan kearifan lokal. Persepsi masyarakat dapat menjadi penentu dalam pengambilan keputusan atau kebijakan (Samehe \& Kindangen, 2015), sehingga diharapkan persepsi masyarakat tentang ekowisata mangrove dan pengelolaannya dapat membantu otoritas pengelola untuk mengambil kebijakan.

Tabel 7. Persepsi Masyarakat tentang Ekowisata Mangrove dan Pengelolaannya

\begin{tabular}{|c|c|c|c|}
\hline & Pertanyaan & $\begin{array}{l}\text { Rataan } \\
\text { Persepsi }\end{array}$ & Keterangan \\
\hline Persepsi & Pemahaman tentang ekosistem mangrove & 4,10 & Baik \\
\hline masyarakat tentang & Pemahaman tentang ekowisata & 3,87 & Baik \\
\hline ekowisata dan & Kondisi ekosistem mangrove & 4,10 & Baik \\
\hline Kondisi Ekosistem & Keindahan ekosistem Mangrove & 4,12 & Baik \\
\hline Mangrove & Kondisi kenyamanan lokasi ekowisata mangrove & 4,03 & Baik \\
\hline & $\begin{array}{l}\text { Keterlibatan mayarakat dalam pengelolaan ekowisata } \\
\text { dan pelestarian ekosistem mangrove }\end{array}$ & 3,60 & Baik \\
\hline Persepsi & Kondisi fasilitas umum & 4,07 & Baik \\
\hline masyarakat tentang & kondisi Listrik/ Penerangan & 4,38 & Baik \\
\hline fasilitas, & kondisi jaringan komunikasi & 4,52 & Baik \\
\hline aksesibilitas dan & Kondisi fasilitas air minum / bersih & 4,18 & Baik \\
\hline Promosi Ekowisata & Kondisi Jalan & 4,05 & Baik \\
\hline & Kemudahan transportasi & 4,13 & Baik \\
\hline & Kondisi keamanan & 4,53 & Sangat Baik \\
\hline & Kondisi kebersihan & 3,90 & Baik \\
\hline & Promosi Ekowisata & 3,32 & Cukup Baik \\
\hline $\begin{array}{l}\text { Persepsi } \\
\text { masyarakat }\end{array}$ & $\begin{array}{l}\text { Ekowisata mangrove dapat meningkatkan } \\
\text { pendapatan masyarakat }\end{array}$ & 4,20 & Setuju \\
\hline mengenai & Ekowisata mangrove dapat menarik minat investor & 3,72 & Setuju \\
\hline $\begin{array}{l}\text { pengelolaan } \\
\text { ekowisata }\end{array}$ & $\begin{array}{l}\text { Kawasan mangrove perlu dipertahankan dan dikelola } \\
\text { secara lestari }\end{array}$ & 4,33 & Setuju \\
\hline mangrove & Pengelolaan mangrove perlu melibatkan masyarakat & 4,23 & Setuju \\
\hline & $\begin{array}{l}\text { Perlu adanya kelembagaan dan kerjasama dengan } \\
\text { pemerintah }\end{array}$ & 4,12 & Setuju \\
\hline & $\begin{array}{l}\text { Perlu adanya peraturan dalam pengelolaan kawasan } \\
\text { mangrove }\end{array}$ & 4,27 & Setuju \\
\hline & $\begin{array}{l}\text { Masyarakat harus menaati peraturan dalam } \\
\text { pengelolaan ekowisata }\end{array}$ & 4,32 & Setuju \\
\hline & $\begin{array}{l}\text { Bentuk pengelolaan harus sesuai dengan kearifan } \\
\text { lokal masyarakat }\end{array}$ & 4,23 & Setuju \\
\hline Persepsi & Kondisi ekosistem mangrove & 4,07 & Baik \\
\hline pengunjung & Keindahan ekosistem Mangrove & 3,57 & Baik \\
\hline mengenai & Kenyamanan lokasi ekowisata mangrove & 4,10 & Baik \\
\hline ekowisata & Kondisi fasilitas umum & 3,50 & Baik \\
\hline & kondisi jaringan komunikasi & 3,53 & Baik \\
\hline & Kondisi fasilitas air bersih & 3,57 & Baik \\
\hline & Kondisi Jalan & 3,97 & Baik \\
\hline & Kemudahan transportasi & 3,67 & Baik \\
\hline & Kondisi keamanan & 3,90 & Baik \\
\hline
\end{tabular}




\section{Analisis SWOT}

Prioritas strategi diperoleh dari Focus Group Discussion (FGD) dengan kelompok Berakit Lestari dengan memperhatikan faktor-faktor yang saling terkait. Ranking strategi ditentukan berdasarkan jumlah skor yang tertinggi sampai skor yang terendah. Hasil analisis prioritas strategi disajikan pada Tabel 8.

Tabel 8. Analisis Alternatif Strategi

\begin{tabular}{|c|c|c|c|}
\hline Alternatif Strategi & Analisis Skor & $\begin{array}{l}\text { Jumlah } \\
\text { Skor }\end{array}$ & Ranking \\
\hline \multicolumn{4}{|l|}{ Strategi S-O } \\
\hline $\begin{array}{l}\text { Melakukan promosi dan publikasi mengenai } \\
\text { ekoswisata mangrove di Desa Berakit. }\end{array}$ & (S1, S2, S5; 01, 02) & 1,55 & 2 \\
\hline $\begin{array}{l}\text { Mengembangkan dan memfasilitasi } \\
\text { kebudayaan asli suku laut. }\end{array}$ & (S3, S4; O3) & 0,82 & 9 \\
\hline $\begin{array}{l}\text { Mengembangkan paket ekowisata yang } \\
\text { menarik. }\end{array}$ & $\begin{array}{l}((\mathrm{S} 6, \mathrm{~S} 7, \mathrm{~S} 8 ; 04,05 \\
\text { O6) }\end{array}$ & 1,79 & 1 \\
\hline \multicolumn{4}{|l|}{ Strategi W-O } \\
\hline $\begin{array}{l}\text { Menyelesaikan jalur tracking dan } \\
\text { membangun Home Stay / penginapan. }\end{array}$ & (W1, W2, 01) & 1,00 & 7 \\
\hline $\begin{array}{l}\text { Membuat detail perencanaan kawasan } \\
\text { ekowisata antar objek di Desa Berakit.. }\end{array}$ & (W3; 02, 03, 04) & 1,13 & 5 \\
\hline Membangun fasilitas pendukung ekowisata. & $(\mathrm{W} 4,05)$ & 0,57 & 12 \\
\hline $\begin{array}{l}\text { Melakukan pelatihan SDM dan membuat } \\
\text { event dan atraksi ekowisata yang menarik } \\
\text { dan berkelanjutan. }\end{array}$ & (W5, W6:06) & 0,77 & 10 \\
\hline \multicolumn{4}{|l|}{ Strategi S-T } \\
\hline $\begin{array}{l}\text { Membuat Peraturan Desa mengenai } \\
\text { perlindungan Ekosistem Mangrove. }\end{array}$ & $(\mathrm{S} 1 ; \mathrm{T} 6)$ & 0,51 & 15 \\
\hline $\begin{array}{l}\text { Mencari Investor/Bapak angkat untuk } \\
\text { membantu pembiayaan pembangunan } \\
\text { fasilitas dan akomodasi. }\end{array}$ & (S2, S5; T1) & 0,73 & 11 \\
\hline $\begin{array}{l}\text { Melibatkan masyarakat untuk berpartisipasi } \\
\text { mengelola ekowisata melaui kelompok Brakit } \\
\text { Lestari. }\end{array}$ & (S3, S4; T2, T5). & 1,14 & 4 \\
\hline $\begin{array}{l}\text { Menyediakan tempat pembuangan sampah } \\
\text { pada titik keramaian dan melakukan } \\
\text { pembersihan pantai yang terdampak } \\
\text { pencemaran akibat tumpahan minyak. }\end{array}$ & (S6, S7, S8; T3, T4) & 1,43 & 3 \\
\hline \multicolumn{4}{|l|}{ Strategi W-T } \\
\hline $\begin{array}{l}\text { Melakukan pemeliharaan jalur tracking yang } \\
\text { telah ada. }\end{array}$ & (W1, W2, W4; T1) & 0,98 & 8 \\
\hline $\begin{array}{l}\text { Mengelakukan perencanaan dan } \\
\text { pengelolaan ekowisata secara transparan }\end{array}$ & (W3; T2, ) & 0,52 & 14 \\
\hline
\end{tabular}




\begin{tabular}{llcc}
\hline \multicolumn{1}{c}{ Alternatif Strategi } & \multicolumn{1}{c}{ Analisis Skor } & $\begin{array}{c}\text { Jumlah } \\
\text { Skor }\end{array}$ & Ranking \\
\hline dan bertanggung jawab. & & & \\
\hline $\begin{array}{l}\text { Melakukan penyuluhan dan penguatan } \\
\text { kesadaran lingkungan untuk bersama-sama } \\
\text { menjaga kelestarian Ekosistem. }\end{array}$ & $(\mathrm{W} 5 ; \mathrm{T3}, \mathrm{T4}, \mathrm{T6})$ & & \\
$\begin{array}{l}\text { Perlu adanya peningkatan infrastruktur dan } \\
\text { fasilitas pendukung di Desa Berakit. }\end{array}$ & $(\mathrm{W} 6 ; \mathrm{T} 5)$ & 0,53 & 13 \\
\hline
\end{tabular}

Pengelolaan diperlukan untuk mengatur, mengendalikan, mengurus, menyelenggarakan dan menjalankan suatu kegiatan (Habsari, 2016) Berdasarkan analisis SWOT (Tabel 8), maka diperoleh tiga strategi prioritas untuk rencana pengelolaan ekowisata mangrove di Desa Berakit sebagai berikut.

1) Mengembangkan paket ekowisata yang menarik.

2) Melakukan promosi dan publikasi mengenai ekoswisata mangrove di Desa Berakit.

3) Menyediakan tempat pembuangan sampah pada titik keramaian dan melakukan pembersihan pantai yang terdampak pencemaran akibat tumpahan minyak (Sludge Oii).

\section{SIMPULAN}

Hasil analisis penghitungan daya dukung ekosistem mangrove di Desa Berakit untuk jelajah mangrove track adalah 214 orang per hari, sedangkan untuk jelajah mangrove berperahu adalah 231 orang perhari. Berdasarkan hasil perhitungan tujuh parameter kesesuaian wisata diperoleh hasil Indeks Kesesuaian Wisata Ekosistem Mangrove adalah 87,50\% termasuk dalam kategori sangat sesuai (S1). Persepsi responden tentang ekowisata mangrove dan pengelolaannya adalah baik, serta berpotensi untuk dikembangkan untuk kegiatan ekowisata. Strategi pengelolaan ekowisata yang dapat dipilih adalah melakukan promosi dan publikasi mengenai ekoswisata mangrove di Desa Berakit, mengembangkan paket ekowisata yang menarik, menyediakan tempat pembuangan sampah pada titik keramaian dan melakukan pembersihan pantai yang terdampak pencemaran akibat tumpahan minyak.

\section{REFERENSI}

Badan Pusat Statistik. (2017). Bintan dalam angka 2017. Bintan: Badan Pusat Statistik Kabupaten Bintan.

Chanafi, A., Fauzi, A., \& Sunarti. (2015). Pengaruh persepsi masyarakat terhadap implementasi Corporate Sosial Resonsibility (CSR) dan dampaknya pada citra perusahaan (Survei pada masyarakat sekitar PT Greenfields Indonesia yang bertempat tinggal di RW 02 Dusun Maduarjo Desa Babadan Kecamatan Ngajum Kabupaten Malang. Malang. Jurnal Administrasi Bisnis (JAB), 3 (1): 1-7.

Habsari, R.D. (2016). Implementasi Peraturan Daerah Nomor 2 Tahun 2011 tentang Pengelolaan Sampah di Kelurahan Karang Anyar Kecamatan Sungai Kunjang Kota Samarinda. Samarinda. Jurnal Ilmu Pemerintahan, 4 (1): 282-293.

Hakim, L., Siswanto, D., \& Nakagoshi, N. (2017). Mangrove conservation in east jawa: The ecotourism development perspectives. The Journal of Tropical Life Science, 7 (3): 277-285. 
Kusumastanto, T., Damar A., \& Adrianto, L. (2012). Pengelolaan Wilayah Pesisir dan Laut. Tangerang Selatan: Universitas Terbuka.

Rahmila, Y.I, \& Halim, A.R. (2018). Mangrove forest development determited for ecotourism in mangunharjo village semarang. Semarang: ICENIS 2018. E3S Web of Conferences 73, 04010.

Samehe, J.V. \& Kindangen, P. (2015). Persepsi wisatawan mancanegara dan kunjungan wisata di kota manado sebagai destinasi ekowisata. Jurnal Berkala IImiah Efisiensi ,15 (5): 515-527.

Triastuti, I. (2015). Model ekowisata dalam perfektif hukum konservasi sumberdaya alam hayati dan ekosistemnya (Hukum Lingkungan). Bogor: UIK Press.

Yulianda F. (2007). Ekowisata bahari sebagai alternatif pemanfaatan sumber daya pesisir berbasis konservasi. Makalah Seminar Sains 21 Februari 2007. Departemen Manajemen Sumberdaya Perikanan, FPIK IPB. Bogor. 